\title{
NOTE
}

\section{Bremerhaven Caisson for intertidal field studies}

\author{
H. Farke ${ }^{1}$, M. Schulz-Baldes ${ }^{1}$, K. Ohm ${ }^{1}$ and S. A. Gerlach ${ }^{2}$ \\ I Institut für Meeresforschung Bremerhaven, Am Handelshafen 12, D-2850 Bremerhaven, Federal Republic of Germany \\ ${ }^{2}$ Institut für Meereskunde, Düsternbrooker Weg 20, D-2300 Kiel, Federal Republic of Germany
}

ABSTRACT: The Bremerhaven Caisson has been designed for field experiments in ecosystem research and pollution studies in intertidal areas. The container-like construction (5.6 $\mathrm{m}$ long, $2.35 \mathrm{~m}$ wide, $2 \mathrm{~m}$ high) has an open top and bottom and encloses an area of $13 \mathrm{~m}^{2}$. The interior of the caisson is connected with the surrounding tidal area by a tube system which functions as water inlet/outlet resulting in total water exchange twice a day according to the tidal rhythm. In long-term pollution studies the pollutant must be added every flood tide. Automatic dosing is used for pollutant addition. Due to periodic water exchange, only short-term investigations are possible on seston and plankton, while long-term studies may be carried out on the enclosed sediment and benthic organisms. The caisson is mobile and can be towed by detachable floats to or from the experimental site. As no severe disturbances of the site occur upon refloating, postexperimental effects can be studied under natural environmental conditions.

Micro- or mesocoms have increasingly received attention during the last decade. In the definitions of Banse (1982) and Grice and Reeve (1982), mesocosms must be larger than benchtop container systems but smaller than large empondments, bays, or small lakes. Mesocosms used in plankton research, for example, are the Kiel Plankton Tower, the Hamburg Enclosure, and the CEPEX Enclosure (see Grice and Reeve, 1982). Only a few mesocosms like the land-based MERLtanks incorporate planktonic and benthic systems and allow the study of exchange processes between both (Banse, 1982).

With a volume of ca. $13 \mathrm{~m}^{3}$ water at high tide and an enclosed area of $13 \mathrm{~m}^{2}$ the Bremerhaven Caisson (Fig. 1) is a mesocosm. The system is designed for field experiments on ecosystem or pollution research in intertidal areas, but use in shallow parts of lakes or rivers is also possible. The caisson allows short-term plankton and seston investigations, long-term benthos research, and studies on the interrelations of planktonic and benthic systems. The unit is mobile, and experiments can be conducted from a few days up to 1 or 2 mo. Related systems are the 'Large indoor tidal mud-flat ecosystem' at the Netherlands Institute of Sea Research, Texel (de Wilde and Kuipers, 1977), and an immobile system of wooden basins enclosing an intertidal mussel bed, which was used in the early seventies for heavy metal studies (de Wolf et al., 1972).
Fig. 1. Bremerhaven Caissons in intertidal area, German Bight

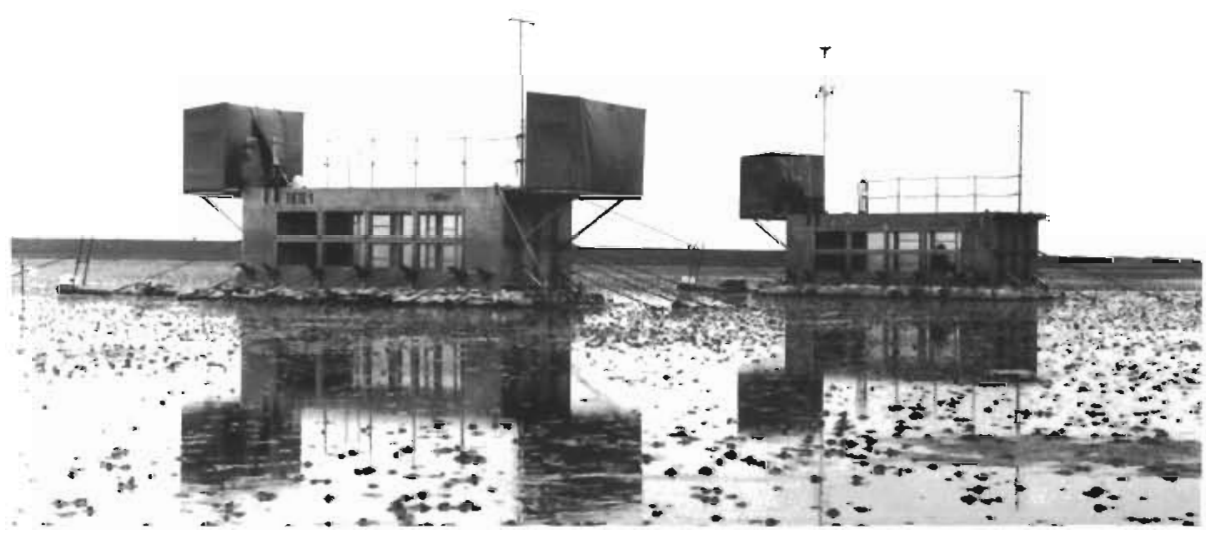


Technical description and operation. The Bremerhaven Caisson is a rectangular, container-like construction $5.6 \mathrm{~m}$ long, $2.35 \mathrm{~m}$ wide, and $2 \mathrm{~m}$ high with open top and bottom. It encompasses an area of ca. $13 \mathrm{~m}^{2}$ (Fig. 2). The main parts of the caisson, which can be and held in place by supports. Once in position the caisson strands with the receding tide and the floats will be detached. At the end of the experimental period the caisson is refloated. The area previously occupied by the caisson can be marked and further

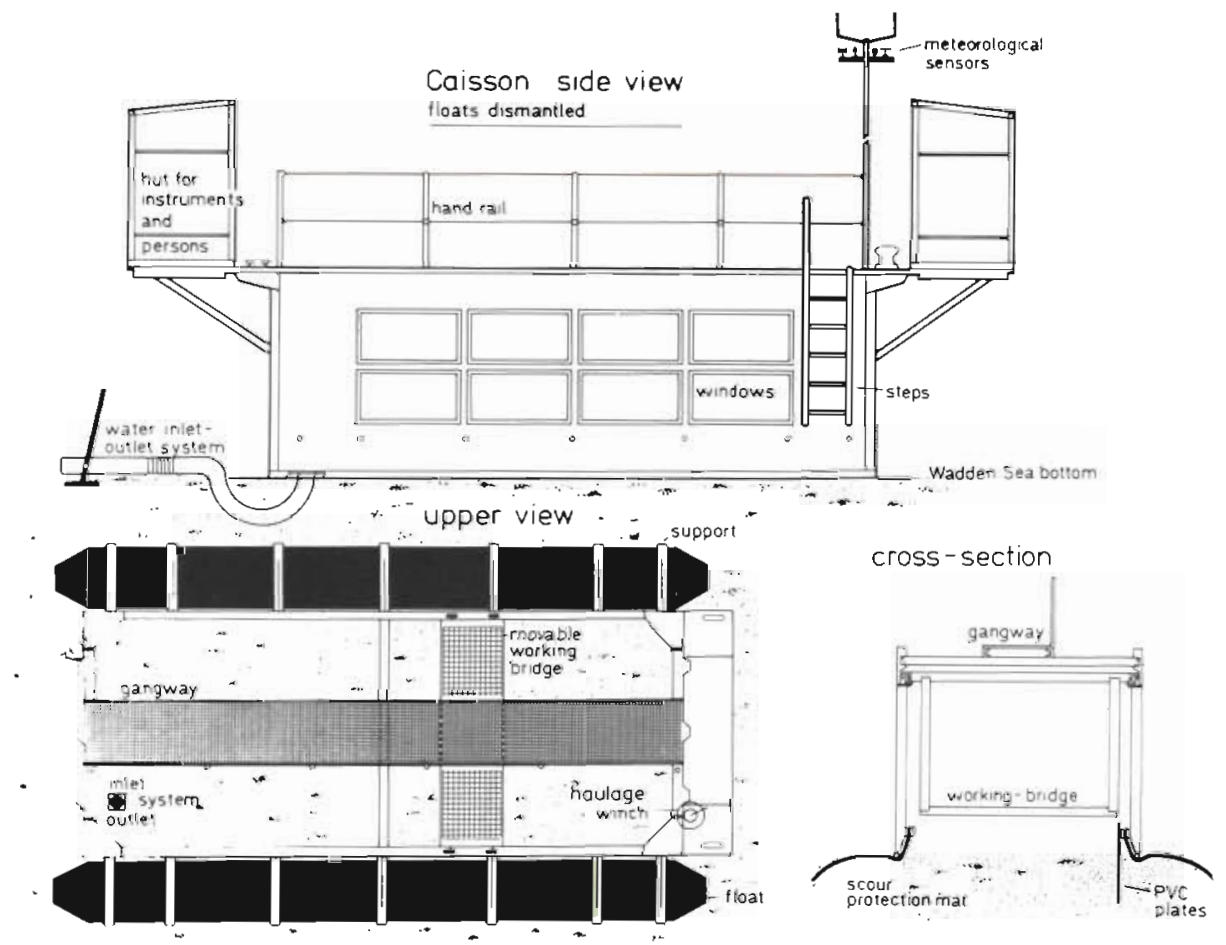

Fig. 2. Caisson and equipment

disassembled for long-distance transport, are 2 sidewalls and 2 frontwalls made from sea-water proof aluminium (Al Mg 4.5; $\mathrm{Al} \mathrm{Mg} \mathrm{3)} \mathrm{and} \mathrm{connected} \mathrm{by}$ stainless steel screws. Each sidewall has 8 Lexan (Polycarbonate) windows $(0.44 \times 0.9 \mathrm{~m})$ to reduce shading. Two platforms at the upper edge of each frontwall can hold canvas shelters $(1 \times 2.35 \times 1.5 \mathrm{~m})$ for instruments and crew. The platforms are connected by a gangway. A movable working bridge inside the caisson allows sediment and benthos sampling without walking on the enclosed bottom area.

During the experiment the caisson, equipped with scour protection mats at the wall-sediment interface, rests on the sediment surface. The interior is connected to the surrounding tidal area by a tube system which functions as water inlet during flood and as outlet during ebb tide. The caisson is held in place by a number of ropes fastened to $1 \mathrm{~m}$ long pins hammered into the bottom (Fig. 3).

The caisson is transported by ship to a tidal channel or by truck to a harbour in the vicinity of the selected tidal flat. From there it is towed by a small boat with shallow draught to the experimental site. The caisson is floatable by 2 rubber floats attached to the sidewalls sampled for studies on loss and degradation under natural conditions. A fully equipped caisson has a weight of $1.5 \mathrm{t}$ and a draught of $0.3 \mathrm{~m}$. Two identical units are at disposal of the Institut für Meeresforschung Bremerhaven.

Equipment and field experience. A prerequisite for Caisson operation is effective protection against scour. We have employed a 2 layer synthetic mat used in aquatic engineering. The lower layer is of felt-like

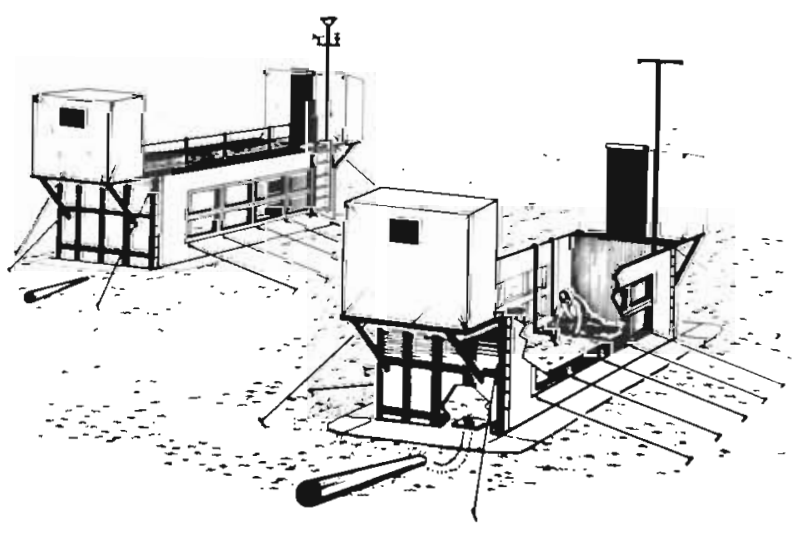

Fig. 3. Bremerhaven Caissons in operation 
material, and the upper layer has a spongy consistence which diminishes water-current velocities and accelerates sedimentation. The $1 \mathrm{~m}$ broad mats are fastened inside the caisson at the lower edge of the walls. From there they bend underneath the walls to the outside so that the caisson rests upon them after positioning. The outside edge of the mats is dug into the bottom resulting in smooth transition between sediment and mats. During stormy periods additional mats ( $2 \mathrm{~m}$ broad) are placed around the caisson. Sandbags are densely packed onto the mats to prevent movement of the caisson.

The interior of the caisson is connected to the ambient environment by a tube system, thus providing a natural tidal regime inside the caisson. The tubes are not integrated into the walls but run through the sediment underneath a frontwall in a u-shaped bend, forcing the incoming water into a vertical direction to minimize scour around the tube opening. In the surrounding tidal flat the u-shaped tube is elongated horizontally by a $3 \mathrm{~m}$ long, partly flexible tube extension with fixed floats that allow the outside opening to follow the rising and falling tide. This avoids inflow of exclusively near-bottom water which is often highly loaded with suspended matter.

Tidal currents are excluded from the interior of the caisson, but turbulence and mixing processes are, to a certain degree, caused by the inflowing water. Experiments with fluorescent dye (Uranin) showed sufficient mixing only during periods of high inflow rates. During field trials in May 1981, a period of calm weather and a very high load of organic matter from an algal bloom caused oxygen depletion near the bottom. For additional water circulation inside the caisson, 2 pumps, working at a rate of $12 \mathrm{~m}^{3} \mathrm{~h}^{-1}$, produce a gentle current above the sediment surface. The pumps are automatically switched on and off by the rising or falling tide. The circulating water is pumped to an outlet system consisting of 10 parallel tubes distributed over the breadth of the caisson at one frontwall about $0.15 \mathrm{~m}$ above the sediment surface. A similar system is installed at the opposite side; it functions as a water inlet. Oxygen depletion was never observed during subsequent experiments.

An apparatus for dosing soluble pollutants (Fig. 4) consists of a supply vessel, an electronic pump, a tidegauge, and an electronic control unit. The purpose of the device is to keep the concentration of a chosen pollutant constant during the tide.

In the control unit 2 voltages are compared: one is proportional to the total revolutions of the pump, the other is derived from a potentiometer attached to the tide-gauge. If the voltage from the gauge exceeds the voltage from the pump, the pump is switched on and runs until both are equal. Thus every $2 \mathrm{~cm}$ increase in water level triggers the addition of $120 \mathrm{~cm}^{3}$ solution from a supply vessel. In terms of the caisson dimension this equals $1 \mathrm{dm}^{3}$ of solution for $2.2 \mathrm{~m}^{3}$ of sea water. The solution is added only during rising tide. The first dose can be increased taking into account a dead time until operation of the tide-gauge. The control unit allows digital read-out of actual water levels and stores the value of the last high-tide level. At the beginning of the next rising tide the instrument is reset automatically. The unit is powered by a rechargeable car battery, one charge lasting $1 \mathrm{wk}$.

Measurements of environmental parameters. Meteorological data (wind speed, wind direction, air temperature, radiation, precipitation) and hydrographic data (sediment temperature, water temperature, salinity, water turbidity, water level) are recorded continuously and stored on magnetic tape (Aanderaa data logger, modified Aanderaa current meter; Fig. 4). A mobile probe for measuring water temperature, salinity, oxygen, and turbidity is available.

Field experience. Two short-term and one long-term field trials were made in $1980 / 81$. The first trial showed that caisson transport by ship, towing, and positioning on the flat caused no major problems. Towing is possible up to a wind speed of $10 \mathrm{~m} \mathrm{~s}^{-1}$, positioning on the flat within $\pm 30 \mathrm{~cm}$; hence the experimental site can be prepared before beginning the experiment.

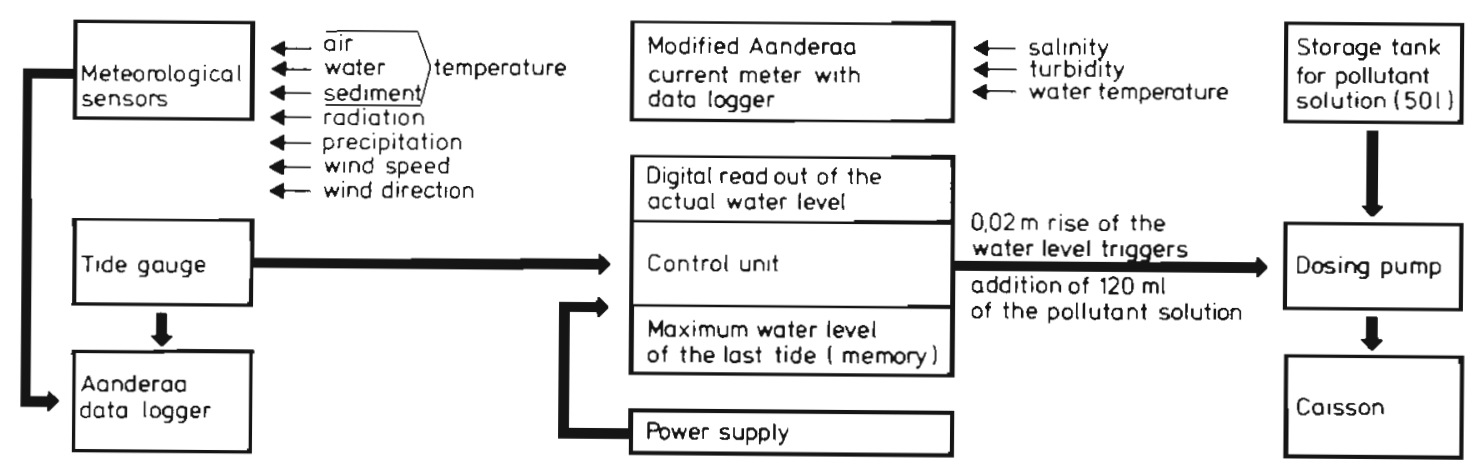

Fig. 4. Scheme of electronic equipment and pollutant addition 
The caissons cannot be operated without scour protection. A test on a sand flat resulted in heavy scour with ditches around the walls 30 to $80 \mathrm{~cm}$ deep. While protection mats and sandbags provide sufficient protection, the sediment beneath the mats becomes anoxic within a few days. The interior of the caisson is protected against this anoxic stress from the outside by plastic plates pushed into the sediment along the inner side of the caisson walls.

Caisson effects, due to diminished light, higher temperatures, increased sedimentation rates, wall effects, and exclusion of large predators, are unavoidable. Compared to the ambient tidal flat, decrease in light intensity causes a reduction in primary production of benthic algae of about $30 \%$ (K. Wonneberger Univ. Oldenburg, pers. comm.). Smaller differences between inside and outside occur for other factors. Even on hot sunny days water and sediment temperatures differ only by 1 to $2 \mathrm{C}^{\circ}$. Sedimentation rates inside the caisson calculated from the decrease of seston concentrations during submersion in the heavymetal experiment 1981 (Schulz-Baldes et al., 1983) were estimated at $0.28 \mathrm{mg}$ dry matter $\mathrm{cm}^{-2} \mathrm{~d}^{-1}$ during calm weather and $1.8 \mathrm{mg} \mathrm{cm} \mathrm{cm}^{-2} \mathrm{~d}^{-1}$ on a stormy day, depending on the seston concentration of the inflowing water and the duration of submersion. As we failed to obtain data on sedimentation rates outside on the flat, direct comparison is not possible. Eisma (1981) estimated the total net sedimentation in the Wadden Sea area at $3 \times 10^{6} \mathrm{t} \mathrm{yr}^{-1}$; from this a sedimentation rate of $0.16 \mathrm{mg} \mathrm{cm}^{-2} \mathrm{~d}^{-1}$ can be calculated. The caisson does not act as a sediment trap: after 3 or $4 \mathrm{wk}$ at the same position, no change of the interior sediment surface was detectable and only a thin layer of mud was deposited on tubes and equipment laying on the bottom. Reworking of the sediment surface by wave action and tidal currents does not prevail inside the caissons. However, abnormal growth of macrobenthic algae or algal mats due to absence of mechanical reworking has not been observed.

We have compared species composition and abundance of macrofauna inside and outside the caisson in a muddy and a sandy area. Samples were taken $10 \mathrm{~d}$ and $24 \mathrm{~d}$ after positioning the caisson. No differences were observed.

By operating the caisson as a flow-through system (total water exchange twice a day, repeated additions of pollutants to inflowing water) long-term effects of pollutants on the benthal can be studied; plankton organisms are exposed to pollutants only during 1 submersion period due to tidal-water exchange. Hence long-term studies of pollution effects on the plankton are not possible. On the other hand, the benthos enclosed by the caisson is provided twice a day with plankton and seston from natural conditions outside the caisson. Mesocosms with little or no water exchange, such as the land-based MERL facility at Narragansett Bay (Pilson et al., 1979) or the 'Large indoor tidal mud flat ecosystem' at Texel (de Wilde and Kuipers, 1977), allow long-term investigations of the planktonic system, but are much more likely to develop their own dynamics then the caisson.

From 1981 to 1983 five long-term experiments (each about $4 \mathrm{wk}$ ) were carried out with 2 caissons on distribution, transfer mechanisms, and bioaccumulation of lead, chromium, and cadmium in an intertidal ecosystem (Prosi et al., 1983; Rehm and Schulz-Baldes, 1983; Schulz-Baldes and Rehm, 1983; Schulz-Baldes et al., 1983). In addition, 6 short-term experiments ( $3 \mathrm{~d}$ and $10 \mathrm{~d}$, respectively) on the fate and biological effects of oil and oil dispersants were conducted (Farke et al., in prep.). During these experiments no major problems were encountered, either with the technical design or with abnormal behaviour of the benthic macrofauna.

Acknowledgements. Development and operation of the Bremerhaven Caissons was made possible by financial support of the 'Bundesminister für Forschung und Technologie', Bonn (Grant No. 0502). The technical design was developed in cooperation with Dipl.-Ing. G. Tietjen ('Reedereigemeinschaft Forschungsschiffahrt', Bremen). The caissons were constructed by 'Fa. Empting', Cuxhaven. We acknowledge the help of Dr.-Ing. G. Luck, 'Forschungsstelle für Insel- und Küstenschutz', Norderney, and the crews of RV 'Victor Hensen', Bremerhaven, RV 'Buise', Norderney, and buoy tender 'Norden', Norderney.

\section{LITERATURE CITED}

Banse, K. (1982). Experimental marine ecosystems in historical perspective. In: Grice, G. D., Reeve, M. R. (ed.) Marine mesocosms. Springer Verlag, New York, p. 10-24

Eisma, D. (1981). Supply and deposition of suspended matter in the North Sea. Spec. Publ. int. Ass. Sediment 5: 415-428

Farke, H., Wonneberger, K., Gunkel, W., Dahlmann, G. (in prep.). Effects of oil and a dispersant on intertidal organisms in field experiments with a mesocosm, the Bremerhaven Caisson

Grice, G. D., Reeve, M. R. (ed.) (1982). Marine mesocosms. Biological and chemical research in experimental ecosystems. Springer Verlag, New York

Pilson, M. E. Q., Oviatt, C. A., Vargo, G. A., Vargo, S. L. (1979). Replicability of MERL microcosms: initial observations. In: Jakhoff, F. S. (ed.) Advances in marine environmental research, EPA - 600/9-79-035, U.S. EPA, Environ. Res. Lab. Narrangansett, R. I., p. 359-381

Prosi, F., Loring, D. M., Müller, G. (1983). Cadmium cycling between water, sediment, and biota in an artificially contaminated mud flat of the North Sea. In: International Conference 'Heavy metals in the environment', Heidelberg, Sept. 1983, Vol 2. CEP Consultants, Ltd., Edinburgh, p. 819-822

Rehm, E., Schulz-Baldes, M. (1983). The adsorption of lead in intertidal sediments. In situ experiments with the Bremerhaven Caisson. In: International Conference 'Heavy 
metals in the environment', Heidelberg, Sept. 1983, Vol 2. CEP Consultants, Ltd., Edinburgh, p. 968-971

Schulz-Baldes, M., Rehm, E. (1983). In situ experiments with the Bremerhaven Caisson on lead and chromium exchange between water, sediment and zoobenthos. In: International Conference 'Heavy metals in the environment', Heidelberg, Sept. 1983, Vol 2. CEP Consultants, Ltd., Edinburgh, p. 1033-1036

Schulz-Baldes, M., Rehm, E., Farke, H. (1983). Field experiments on the fate of lead and chromium in an intertidal benthic mesocosm, the Bremerhaven Caisson. Mar. Biol. 75: $307-318$

Wilde, P. A. W. J. de, Kuipers, B. R. (1977). A large indoor tidal mudflat ecosystem. Helgoländer Meeresunters. 30: 334-342

Wolf, P. de, Kock, W. Ch., Stam, A. (1972). Field experiments on the influence of copper and mercury in a natural mussel bed. TNO-nieuws 27: 497-504

Accepted for printing on November 30, 1983 